\title{
Differential earthquake footprints on the masonry styles at Qal'at al-Subayba (Nimrod fortress) support the theory of its ancient origin
}

\author{
Alon Margalit ${ }^{*}$ (i)
}

\begin{abstract}
Qal'at al-Subayba (Nimrod Fortress), one of the largest medieval fortresses in the Middle East, is strategically located above the city of Banias on the ancient highway from Tyre to Damascus. Scholars have attributed the founding of the fortress to different rulers and periods. Current theory attributes the fortress founding to the Ayyubids. Although the Ayyubic theory is widely accepted, it relies primarily upon alternative interpretation of historical sources rather than firsthand observations. The fortress was constructed using distinctively different masonry styles. The primary styles, Massive, Crusader, Ayyubic, and Mamluk, are characterized here. Some of these masonries carry earthquake footprints and findings show that the damage is correlated with the specific masonry rather than geographical or other constraints. The Massive masonry sustained the greatest damage. The Crusader masonry was damaged to a lesser extent and the Ayyubic and Mamluk were spared. Based on these findings, it is concluded that the fortress was hit by two powerful earthquakes, the one of A.D 749 and the one of A.D 1202. The earthquake of A.D 749 devastated the Massive masonry, prior to later constructions. As this masonry has Hellenistic characteristics, it is suggested that the fortress was founded by the Greco-Syrians.
\end{abstract}

Keywords: Historical earthquakes, Seismic, Fortress masonry, Hellenistic period, Medieval ages

\section{Introduction}

Qal'at al-Subayba, one of the largest medieval fortresses in the Middle East, is located on the foothills of Mount Hermon, four kilometers east of Banias, $33^{\circ} 15^{\prime} 10^{\prime \prime} \mathrm{N}$, $35^{\circ} 42^{\prime} 53^{\prime \prime} \mathrm{E}$ on the DNS. The fortress is situated on a narrow ridge, $120 \mathrm{~m}$ wide and $430 \mathrm{~m}$ long, about 800 meters above sea level, and is naturally protected by steep slopes on its southern, western, and eastern faces, and by a deep ravine to the north. It is strategically located on the ancient road from Tyre to Damascus [1-3]. It dominates the ancient city of Banias (formerly Paneas or Caesarea Philippi) and oversees a vast area, from the Hula marshes to the Ayun Valley (Fig. 1). The only road to the fortress comes from the east and passes below its

*Correspondence: alonmarg@telhai.ac.il

Department of Libraries, Tel-Hai College, Upper Galilee, Israel eastern curtain wall. Its donjon is situated on the highest point of the ridge facing east. The donjon is protected by inner curtain walls and a moat to the west. A schematic description of the fortress compounds and layout is provided in Fig. 2. Although the fortress bears distinct earthquake footprints, many of its sections remain, providing a very fine example of medieval fortress design. Different masonry styles were used in construction. This feature is unique and is not found in other medieval fortresses in the region. Nimrod fortress was declared a National Park in 2003 and is considered an international heritage site and a major tourist attraction.

The first European explorer to visit the site was Ulrich Jasper Seetzen in January 1806. Later, it was visited by numerous explorers, among them John Lewis Burckhardt, Lawrence Oliphant, and Edwin Hodder. The famous nineteenth century explorers, Edward Robinson 


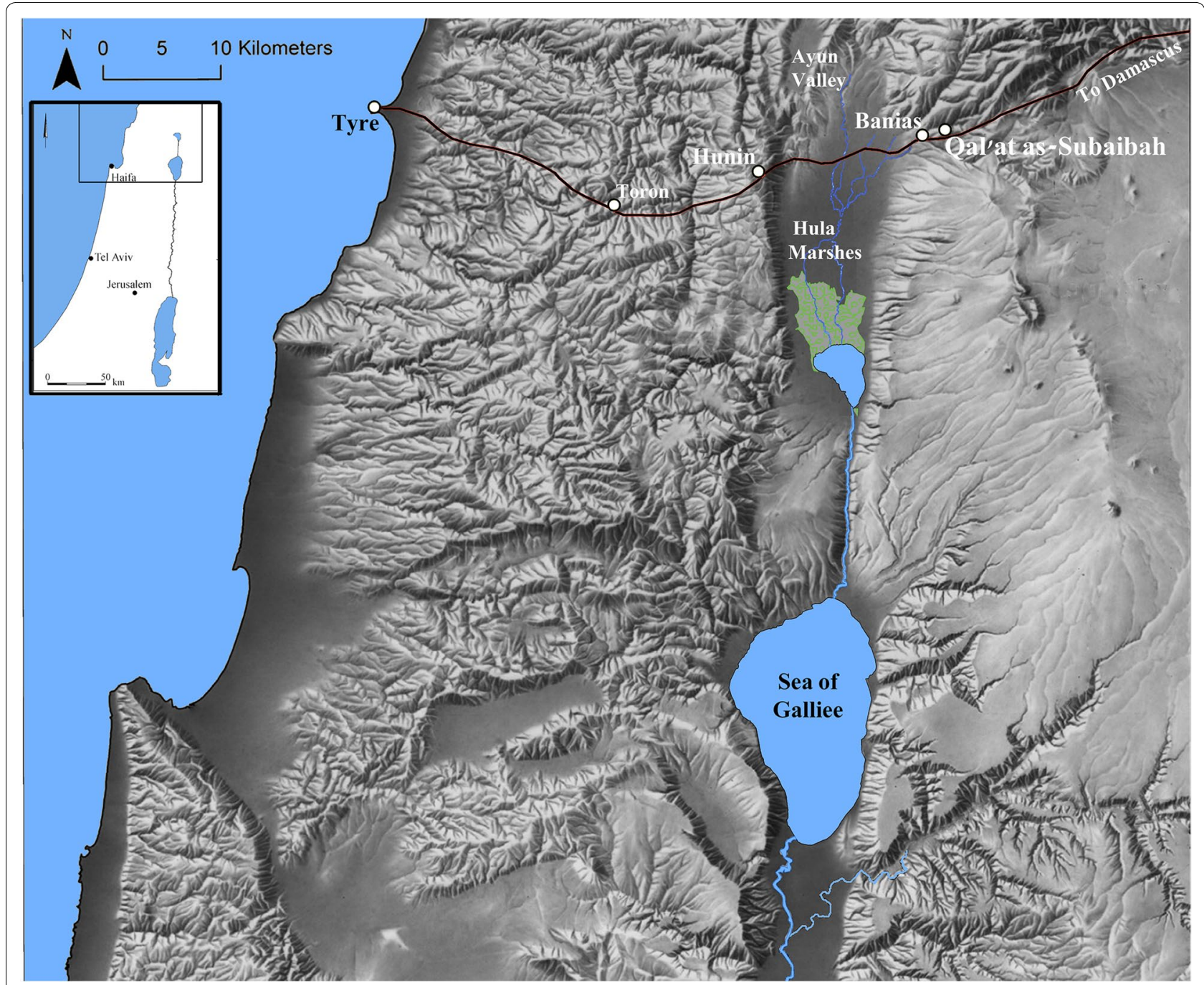

Fig. 1 Fortress location and strategic position. The landscape description reflects medieval times; strongholds along the Tyre-Damascus road are indicated

and Sir Charles William Wilson, who each visited the site in the mid-19th century, described Qal'at al-Subayba as a strong fortress built using different masonry styles from ancient to medieval times [2, 4]. Paul Deschamps explored the fortress in the early 1930s. Deschamps did not subscribe to the ancient origin of the fortress; he argued that the entire fortress is Medieval with typical Templar characteristics [5]. Ronnie Ellenblum, in his manuscript "Who Built Qal'at al-Subayba?" proposed that the fortress was established in the postCrusader era between A.D 1220 and 1230 by the Ayyubic ruler of Banias, Al-Malik Al-Aziz 'Uthman [3]. The Ayyubic theory gained wide popularity and is currently accepted by most scholars [6-9]. However, it is based on an interpretation of historical texts, rather than on firsthand observations or archaeological findings [7]. In addition, the theory does not explain why and how a local ruler constructed such an impressive fortress in a time of war, far from the front, when the necessary resources and professional human workforce were scarce.

A current day visitor to Qal'at al-Subayba cannot ignore the wealth of different masonry styles at the site. Each style has its unique characteristics, from stone size and stone dressing to architectural design. Some of the styles are stratified, one upon the other. As masonry and architecture styles are oftentimes linked to a specific historical era and/or ruler [10], these observations suggest that construction was carried out by different masons during different historical times and under different rulers. 


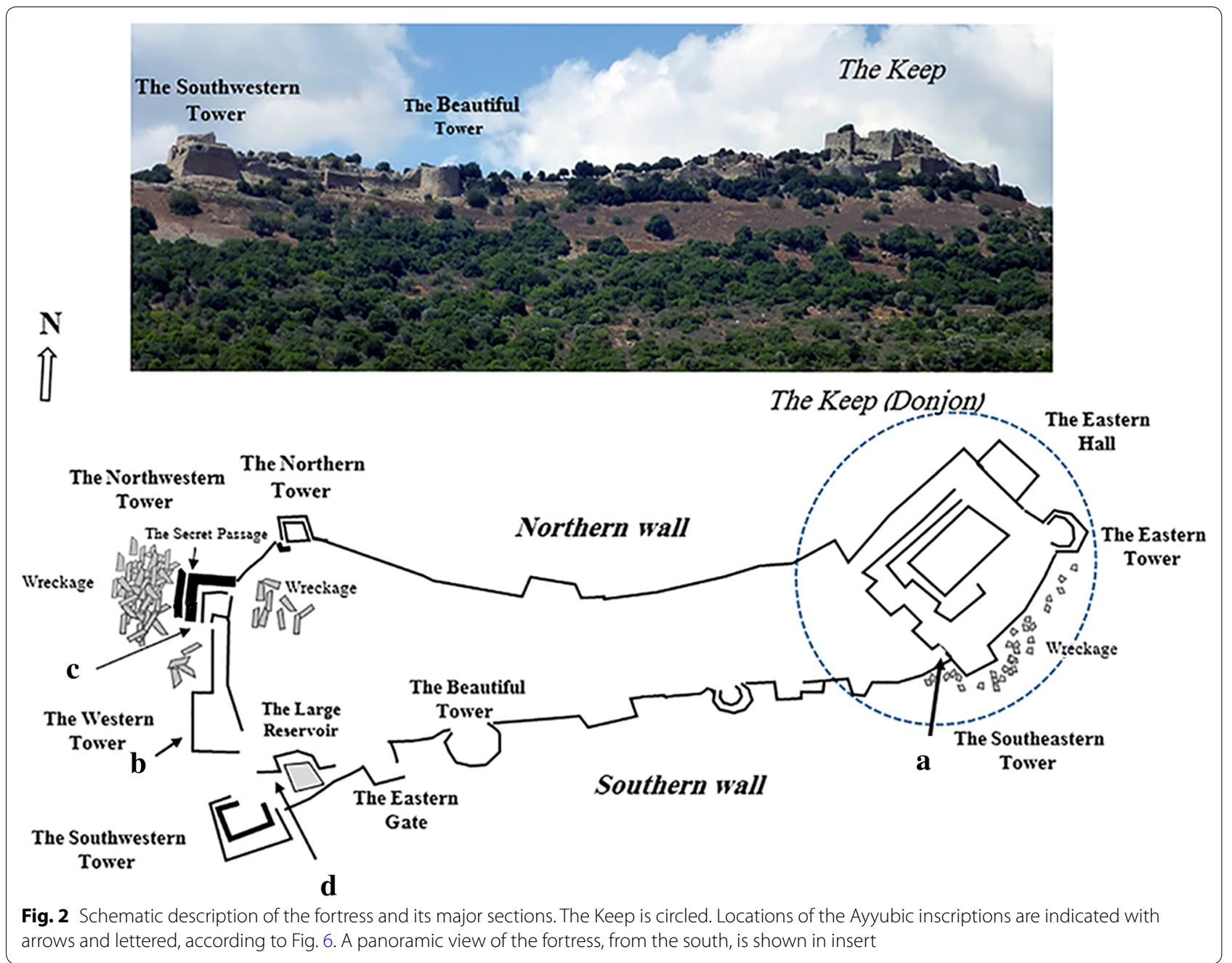

The fortress compound bears clear and distinctive earthquake footprints [9]. These footprints were attributed to a single earthquake, that of A.D $1762[3,6]$. However, close examination of the earthquake marks on the different masonry styles reveals that they were affected differently. While some constructions were severely damaged or even collapsed, others were damaged to a lesser extent, sustaining partial collapse and cracks. Yet others were unaffected and have no visible earthquake marks. These observations lead to the hypothesis that the fortress was constructed over a long period and struck by at least two different earthquakes. According to this hypothesis, the fortress chronology can be divided into three periods, early (before the first earthquake), middle (between the first and the second), and late (after the second earthquake). Associating the different masonry styles to these chronological periods and identifying the relevant earthquakes based on the historical earthquake record might provide a better understanding of the fortress history and when it was founded.

\section{Characterization of the different masonry styles and their earthquake footprints at Qal'at al-Subayba}

Although the wealth of masonry styles is a recognized feature of Qal'at al-Subayba [2], scholars have generally overlooked its significance. This study focused on the different styles, characterizing each according to stone size, stone dressing, architecture, and similarity to masonries in other fortresses. Using these criteria, it was possible to identify four primary styles, Massive, Crusader, Ayyubic, and Mamluk. The description of each style together with its earthquake footprint is provided below. 


\section{Massive masonry}

The Massive masonry is restricted to the Northwestern Tower and adjacent stone wreckage (see Fig. 2 for location). This masonry is characterized by rusticated, trapezoid ashlar of 2-5 m width, 1-2 m height, 1-2 m depth block, weighing between five and 30 tons each [6]. The outer face of the stones' surface is rough, but their contours are delicately and accurately cut and each stone was carved individually to fit snuggly to its neighbors (Fig. 3a, b). The black line under one of the stones in Fig. 2a measures $5 \mathrm{~m}$ length. The quality and precision of the stone dressing are outstanding and, despite their size, each stone was individually fashioned for distinctive shape and role [6].

Notwithstanding its immense size and durability, the Massive masonry sustained earthquake damage on a catastrophic scale, as most of the tower's western face, as well as internal sections utterly, collapsed [9]. The
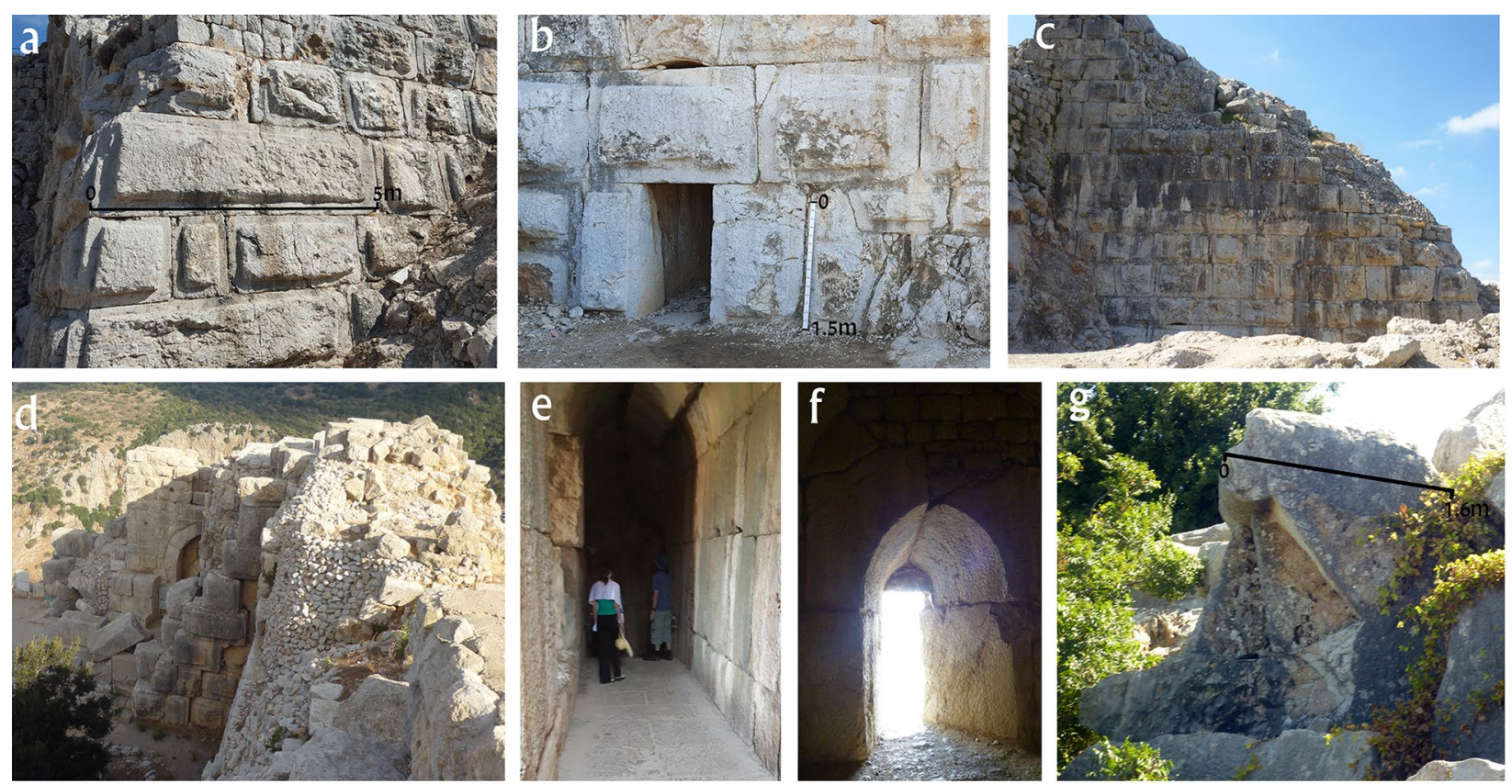

\section{h}

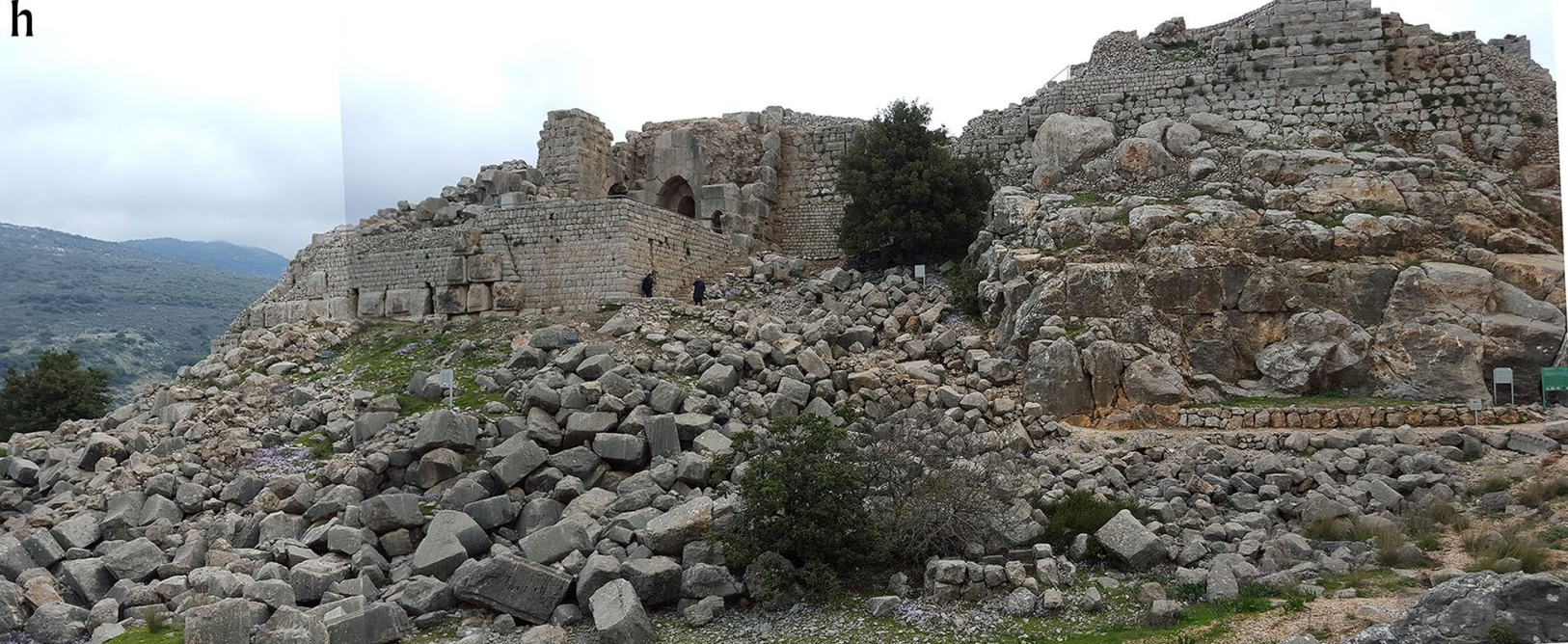

Fig. 3 Massive masonry. a Massive building blocks with single block length indicated. b The 'secret passage' postern, single block height indicated. c Typical trapezoid ashlar, northern face of the northwestern tower. $\mathbf{d}$ Substantial curtain wall destruction, eastern face of the northwestern tower with single block height indicated. e Inside the 'secret passage'. $\mathbf{f}$ Large archer slit at the 'secret passage'. $\mathbf{g}$ Gigantic monolithic fragment of spiral staircase, western wreckage. h. Panoramic view of western wreckage piles 
northern (Fig. 3c) and the southern (Fig. 3d) faces were better preserved, indicating that the horizontal earth motion was south-west. Of the inner sections, a long and narrow corridor termed the 'secret passage' was virtually preserved (Fig. 3e). Interestingly, the two battlements along this corridor are not of the medieval type with narrow arrow slits for crossbow archers, but rather large arrow slits designed to accommodate arrow ballistas (polivolos katapeltes) of the type common in antiquity (Fig. 3f).

The huge wreckage piles to the west are the best evidence of the earthquake's destructive force. The scattering of the stones reaches a radius of about $30 \mathrm{~m}$ and the piles cover a very large area on the western slope (Fig. $3 \mathrm{~h}$ ). Although many of the stones were removed during modern reconstruction activity, the scattering provides quite a good impression of the radius and size of the wreckage. Smaller wreckage piles are located to the east and the north; however, many of the stones were removed or replaced. Sections from a monolithic spiral staircase found among the western wreckage (Fig. 2g) suggest that this section served as a watchtower. The black line in the middle of the image measures $1 \mathrm{~m}$ length.

The Massive masonry encircles an inner tower built in a different masonry style, namely Crusader masonry. Hartal maintained that the Massive masonry was a later addition by the Mamluk ruler Badr ad-Din Bilik, [6]. The current observations do not support this view and suggest that the Massive masonry preceded the other masonry styles at the northwestern tower. This conclusion is based on the following: (1) the Massive masonry sustained the lion's share of the damage while other masonries in the same location were only moderately affected; (2) the wreckage piles comprise only Massive building blocks which would not be possible if both Massive and Crusader masonry constructions existed at the site when the earthquake hit; (3) this type of masonry requires special skills, know-how, resources, time and a huge working force. It is unlikely that these were available to a local ruler.

\section{Crusader masonry}

Crusader masonry is the predominant masonry of the fortress and can be identified throughout the compound. This masonry is characterized by medium-sized, rusticated rectangular blocks (roughly $100 \times 75 \times 75 \mathrm{~cm}$ ). The central portions of the blocks are roughly dressed and surrounded by flat rims (Fig. 4a). The stone dressing displays precise and fine workmanship and the stones fit snuggly together. The black line that crosses one of the stones in Fig. $4 \mathrm{a}$, measures $1 \mathrm{~m}$ length. The stones are shaped in a uniform design with the exception of those used for gates, archery slits, and windows. The curtain walls have three layers, outer and inner ashlars sandwiching rubble fill. The walls were built according to the prevailing crusader fortress structural design that characterizes other crusader fortresses in the region, such as Sahyun and Krak des Chevaliers [11]. Deschamps first noted the resemblance of this style to Crusader masonry [5]. Ellenblum maintained further that the masons at Qal'at al-Subayba were locals who served later rulers as well [3].

The Crusader masonry bears clear earthquake marks, but it was not damaged on a catastrophic scale. Although inner sections suffered from substantial destruction (Fig. 4b-d), the curtain walls, in general, survived the earthquake with the exception of large vertical cracks evident everywhere in the eastern and western sections (Fig. 4e-g). Partial structural collapse and stone wreckages found in close proximity to the walls can be observed to the south (Fig. 4h, i). The wreckage piles and scattering radius are smaller than those of the Massive masonry. The wreckage location to the south and the location of the vertical cracks on the eastern and western curtain walls suggest that the surface motion of this earthquake was in a different direction than the earthquake that hit the Massive masonry (i.e., south-north).

Of the inner sections, only the western wall of the Eastern Hall was partially preserved (Fig. 5, see Fig. 2 for location). Therefore, it is the only place in the castle where one can observe the inner compound architecture. Although the compound suffered severe damage, one can clearly identify rib vault (cross vault) elements. Rib vaults are classical Gothic architecture elements and are found in many Frankish constructions across the region [12]. Since these elements are symbolic, representing the shape of the cross [13], they were not adopted for use by the Muslims.

In conclusion, the Crusader masonry has distinct and typical characteristics of Frankish architecture and carries earthquake footprints that are singularly different from those on the Massive masonry. These footprints indicate that the earthquake damaging the Crusader masonry was of lesser severity and that the earth motion was south-north rather than east-west. Based on these observations, it can be concluded that the earthquakes that hit the Massive and Crusader masonries were different and that the earthquake that hit the Massive masonry occurred prior to the Crusader masonry construction.

\section{Ayyubic masonry}

The Crusaders captured the city of Banias in A.D 1099. During the Crusader reign, the city was the site of fierce fighting and went from hand to hand until it was taken in A.D 1164 by Nur ad-Din Zengī, the Muslim Governor of Damascus. The Ayyubids ruled the region from A.D 1179 

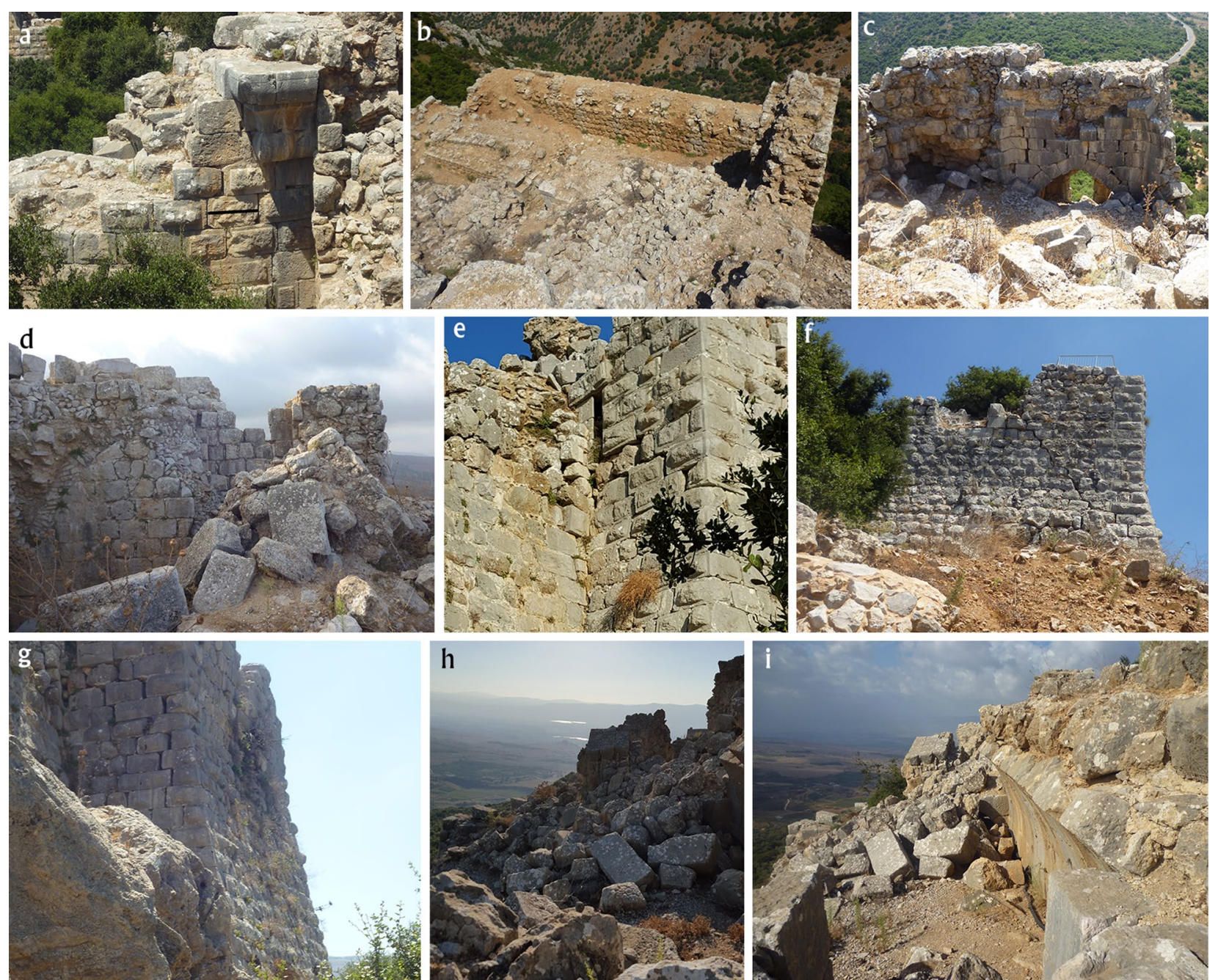

Fig. 4 Crusader masonry. a Typical ashlar, east face, southern tower (tower 2). b-d Examples of severe destruction of inner compounds, different locations. e- $\mathbf{g}$ Examples of vertical cracks on curtain walls, different locations. $\mathbf{h}, \mathbf{i}$ Examples of collapses and wreckages, different locations, eastern face

to 1260. According to Ellenblum's theory the local ruler of Banias, Al-Malik al-Aziz Uthman, founded the fortress in A.D 1227 [3]. Ayyubic inscriptions that were found at the fortress attribute constructions primarily to this ruler $[5,14]$. At least seven inscriptions have been recorded, of them four are embedded, in situ, in walls or other constructions. Stones with the remaining inscriptions were found on the ground [14]. As the extent of Ayyubic construction is questioned in this work, the term Ayyubic masonry, herein, refers only to construction that bears Ayyubic inscriptions. The inscriptions were characterized and deciphered by Reuven Amitai [14].

The first inscription, dated A.D 1227 (Inscription I, Amitai R. 1989), is located on a curtain wall at the western face of the Southeastern Tower (Fig. 6a and insert; see Fig. 2 for location). The wall appears to be a newer addition to a previously existing, partially ruined section built in Crusader masonry style. The ashlar was made from mid-sized, uneven, roughly-dressed stones. The stones do not fit well and small stones are wedged between the larger ones. This style, resembling Ayyubic fortifications at Hunin, Ajloun, and Msaylha fortresses, is a fine example of the Ayyubid fortification strategy, which was not dependent upon fortified strongholds and placed minor importance on masonry quality [15]. This type of low-quality masonry is considered to be highly susceptible to earthquake damage. Nevertheless, the curtain wall bearing an Ayyubic inscription was preserved and carries no visible earthquake damage albeit the clear earthquake footprints on the Crusader masonry upon which it leans. 


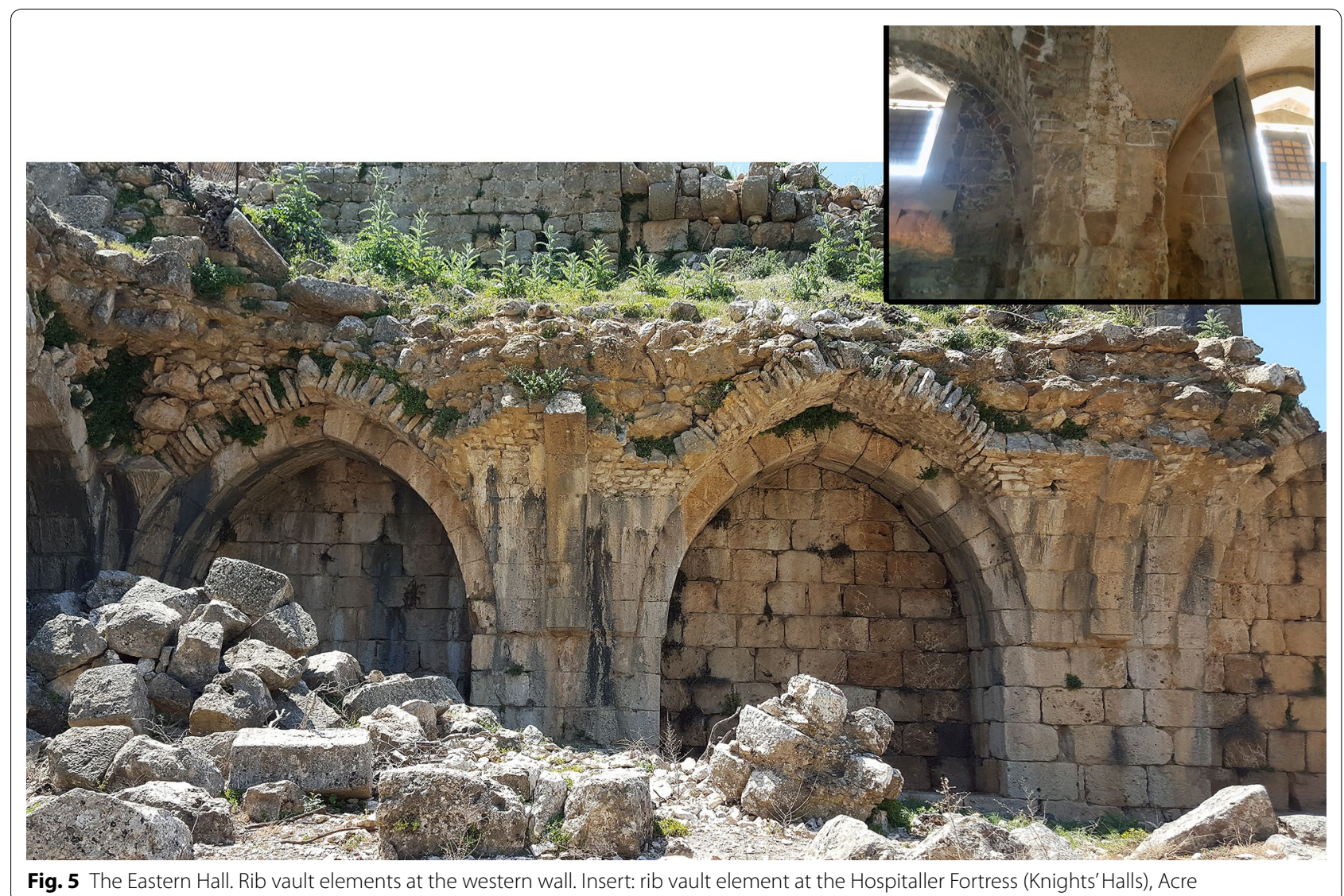

The second inscription, dated to A.D 1230 (Inscription V, Amitai R. 1989), is located at the top of the outer face of the Western Tower (Fig. $6 \mathrm{~b}$ and insert; see Fig. 2 for location). The masonry style is similar to that of the southeastern tower, characterized by uneven, roughlydressed stones that do not fit very well together. Again, this section bears no visible earthquake footprints.

The third Ayyubic inscription, dated to A.D 1230 (Inscription II, Amitai R. 1989), is located on the western gate of the Northwestern Tower. In contrast with the previously described Ayyubic sections, the masonry at this portion of the site is of higher quality and displays the characteristics of Crusader masonry. It also bears clear earthquake marks (Fig. 6c and insert; see Fig. 2 for location). Based on this observation it is concluded that the Ayyubids carved the inscription on a pre-existing, damaged section of masonry.

The fourth Ayyubic inscription, located above the fountain near the southwestern gate, is attributed to the Ayyubic ruler al-Malik al-Sacid Fakhr al-Din in A.D 1240 (Inscription VII, Amitai R. 1989). The inscription is in an undamaged section of the fortress displaying characteristic Ayyubic masonry. In addition, it was apparently carved on a pre-embedded table, as some of the letters were extended from the table to the frame (Fig. $6 \mathrm{~d}$ and insert; see Fig. 2 for location). Ayyubic masonry characteristics, described herein, are found at other locations in the fortress that do not carry Ayyubic inscriptions.

\section{Mamluk masonry}

The Mamluk Sultanate ruled Syria from A.D 1247 to 1517. The Mamluk reconstruction at Qal'at al-Subayba is quite extensive and was carried out predominantly during the rule of Sultan al-Malik al-Zāhir Rukn al-Din Baibars alBunduqdar by the local ruler of Banias, Badr ad-Din Bilik [16]. The exact extent of Mamluk construction at the fortress is under dispute and the Massive masonry has been attributed by some scholars to the Mamluks [3, 6]. It is generally accepted, however, that the Beautiful Tower (Fig. 7a, b; see Fig. 2 for location), the Large Reservoir (Fig. 7c; see Fig. 2 for location), the Southwestern Tower (Fig. 7d-f; see Fig. 2 for location), the Northern Tower (Fig. 7g, h; see Fig. 2 for location), and the Eastern Gate (Fig. 7i; see Fig. 2 for location) are fine examples of Mamluk masonry [3]. The masonry of these structures is similar, characterized by a finely-dressed, medium-sized ashlar, resembling the Crusader. However, the large square halls with their high, arched vaults with no supporting arches (Fig. 7c, h), 

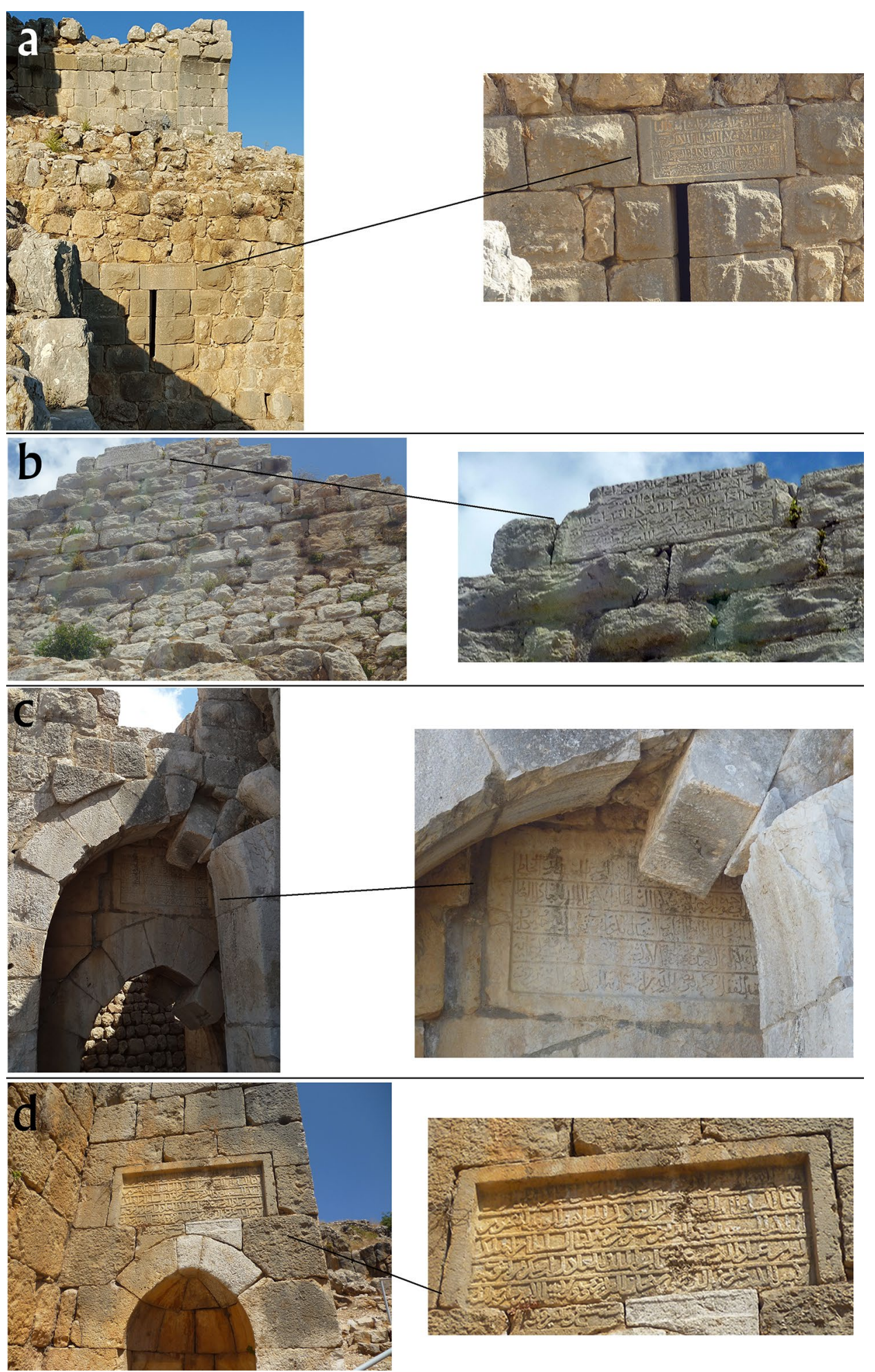

Fig. 6 Ayyubic masonry. a Ayyubic inscription from the year A.D 1227 (625 after hijra, A.H) on the external face of the southwestern Tower. Insert focus on the inscription. b Wall containing Ayyubic inscription from the year A.D 1230 (627 A.H) on the external face of the Western Tower. Insert focus on the inscription. c Ayyubic Inscription from the year A.D 1230 (627 A.H) above the western gate. Insert focus on the inscription. d Ayyubic Inscription from the year A.D 1230 (627 A.H) above the water fountain near the Western Tower 

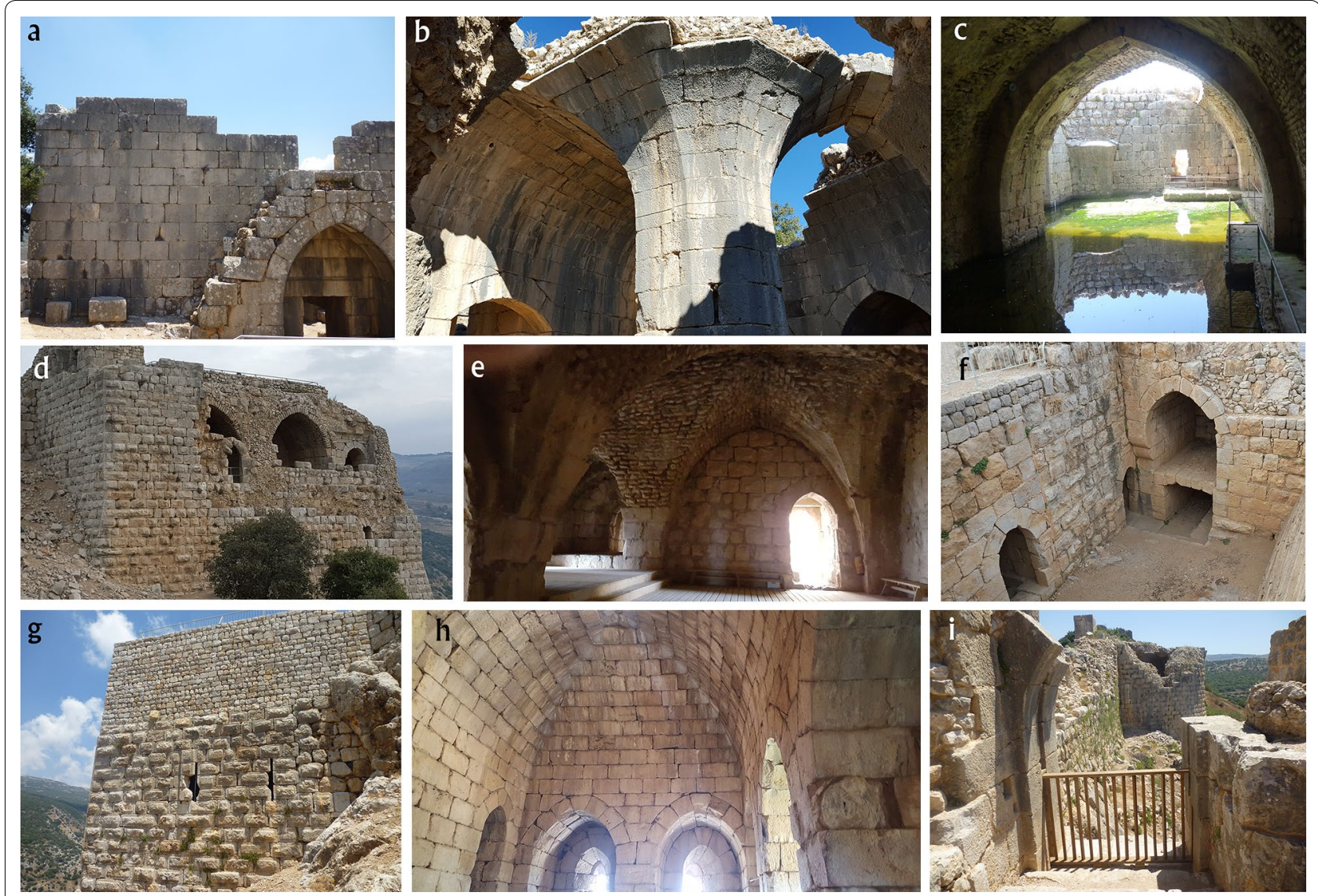

Fig. 7 Mamluk masonry. a Entrance to the Beautiful Tower. $\mathbf{b}$ Internal hall, the Beautiful Tower. $\mathbf{c}$ The large reservoir. $\mathbf{d}$ The western outer face of the Southwestern Tower. e The main hall, Southwestern Tower. $\mathbf{f}$ The courtyard, Southwestern Tower. $\mathbf{g}$ Entrance to the Northern Tower. $\mathbf{h}$ The main hall, Northern Tower. $\mathbf{i}$ The northern outer face of the Northern Tower. $\mathbf{j}$ The eastern gate

characterizes Mamluk fortifications throughout the region [15]. This style of architecture is considered to be sensitive to earth motion and unable to withstand even moderate earthquakes [17]. Surprisingly, the Mamluk compounds were preserved and have no visible earthquake footprints. The beautiful tower is a good example of this phenomenon. Its main hall is built around a central stone ledge pier that curves outward to support a domed ceiling. The pier blocks are held together by cement with no additional support. Although this architecture is susceptible to even moderate earthquakes it is undamaged, while adjacent constructions were damaged significantly. Based on these observations, it is suggested that the Mamluk masonry was set after the earthquake(s) and represents the late period of the fortress chronology.

\section{Discussion}

\section{Association of earthquake footprints with different} masonries

Different masonries at Qal'at al-Subayba have been reported by scholars [5]. However, this is the first study to define four different masonry styles, provide a chronological order for these masonries based on stratification, and to characterize the earthquake footprints associated with each style. A primary finding of this work is that the severity of earthquake damage is strongly associated with and confined to only two of the four masonries, namely the Massive and the Crusader. The Mamluk and the Ayyubic masonries are devoid of earthquake marks. It is currently assumed that the damage resulted from a single quake, namely the earthquake of 1759 [3, 6]. It should be taken into account, however, that in 1759 there were two earthquakes. The one that devastated Tiberias and Safed was different from that which devastated Baalbek, and the EQ that had the potential to affect the fortress was that which ran along the Serghaya Fault [18]. Based on this record and others, the intensity of this EQ in the Golan Heights cannot explain the damage to the fortress. In addition, on that date, the fortress was already deserted (Wilson FC, Caesarea Philippi: Banias, the Lost City of Pan, pp 163-164). By that time, the whole region had gone into obscurity; hence, supporters of damage 
caused by an EQ in 1759 need to account for the tremendous labor and resources required for the extensive restoration seen at the fortress. The discovery that the Ayyubic and Mamluk masonries were not damaged rule out possible association of post-medieval era earthquakes with the damage. A single earthquake can cause minor to major damage or even complete destruction. The extent of damage is highly correlated to magnitude and distance from the source but is also attributed to other factors, such as local surface motion, geological micro and macro constraints, masonry style, architecture, building height and more [19]. Focusing on masonry styles and architecture, it is well established that light buildings, low-quality masonries, and specific architectural designs are more susceptible than others $[17,20,21]$. Hence, if the fortress was hit by a single earthquake, then one would expect that the Ayyubic and the Mamluk masonries would have sustained the most damage and the Massive masonry the least. However, the opposite is found. While the Mamluk and the Ayyubic masonries harbor no earthquakeassociated damage, the Massive masonry was devastated. This is even more striking when taking into account that trapezoid ashlars composed of massive block are known for being highly resistant to earthquake damage [22]. The more plausible explanation for this paradox is that the Ayyubic and Mamluk construction took place after the earthquake(s).

At the northwestern tower, the Massive masonry took the hardest hit, while the Crusader masonry at the same location sustained milder damage. This evidence, in addition to the observation that the stone wreckages are composed of only Massive elements, leads to the conclusion that the Massive masonry destruction preceded the Crusader masonry construction. Taken together, the fortress was hit by at least two major earthquakes, rather than one. The first earthquake caused the destruction of the Massive masonry while the second damaged the Crusader masonry. The Ayyubic and Mamluk masonries were built after the second earthquake.

\section{Historical earthquake record and its implication on the fortress chronology}

The Middle East has a long and continuous history of devastating earthquakes. Although no direct measurements of earthquake magnitude could have been taken, indirect geological and archaeological evidence, together with historical documentation, provide relatively accurate information for the date, site, epicenter, radius, and severity of these earthquakes. Current studies by Ben Menachem and Sbeinati provide a detailed description of the earthquakes recorded over the last 3000 years [23, 24]. Although there are some discrepancies between these reports with regard to time and severity, the discrepancies are insignificant. The illustration of earthquake chronology and severity in Fig. 8 is based on Sbeinati et al. [24].

The observation that the Mamluk masonry was spared rules out the association of the fortress' damage to the earthquakes of A.D 1546, 1759, and 1837. The 1759 earthquake epicenter was far from Banias [24], further evidence that this earthquake did not damage the fortress. The earthquake most likely accountable for the damage is that of A.D 1202. Since this earthquake hit prior to the reign of Al-Malik Al-Aziz 'Uthman, it rules out the Ayyubic theory of foundation and also provides an explanation as to why the Ayyubic masonry was principally spared. The Ayyubic inscription on the northwestern gate (Fig. 6c) appears to be carved on a section of Crusader masonry. According to Reuven Amitai [14], the terminology used in this Ayyubic inscription is 'imara, meaning reconstruction or renewal, rather than 'insha' or 'bina,' the terms for establishment or construction. Hence, the association of the damage to the A.D 1202 earthquake is not contradicted by the Ayyubic texts.

Historical records provide further support for the preAyyubic origin of the fortress. The Muslim historian Ibn-Chadded (1145-1234) described the construction by the Franks of a fortress above the city of Banias [5]. In his work, The Damascus Chronicle of the Crusades, the Muslim historian Ibn Al-Qalanisi (1107-1160) described the handing over in A.D 1128 of the frontier fortress of Banias to the Ismaili sect (Assassins) by Toghtekin, the Seljuk ruler of Damascus. According to the text, the fortress was partially destroyed [25]. Based on the current observations, the Franks had a central role in the fortress' later construction. This conclusion is in agreement with by Deschamps who claimed that the fortress carries Hospitaller characteristics [5]. Ellenblum did not reject this notion; he claimed that the masons were locals who utilized the same technologies when building for the Crusaders, as well for their predecessors [3]. Although this hypothesis is not based on the historical record, it might seem sound. Nevertheless, some of the Frankish architectural characteristics were not adopted by the Muslims in their building. For example, basilica-like building designs and rib vaults, both symbolize the cross. The central hall, at the keep, might have basilica-like characteristics. However, since it was levelled to the ground the association is not definite (not shown). By contrast, rib vault elements can be clearly seen in the Eastern Hall (Fig. 4), providing direct evidence that this section was constructed by the Franks. Based on these findings, it can be concluded that the Crusader masonry is Frankish and that the earthquake damage to this masonry was the result of the A.D 1202 quake. This earthquake has been linked to the damage of several crusader castles in the region, including 


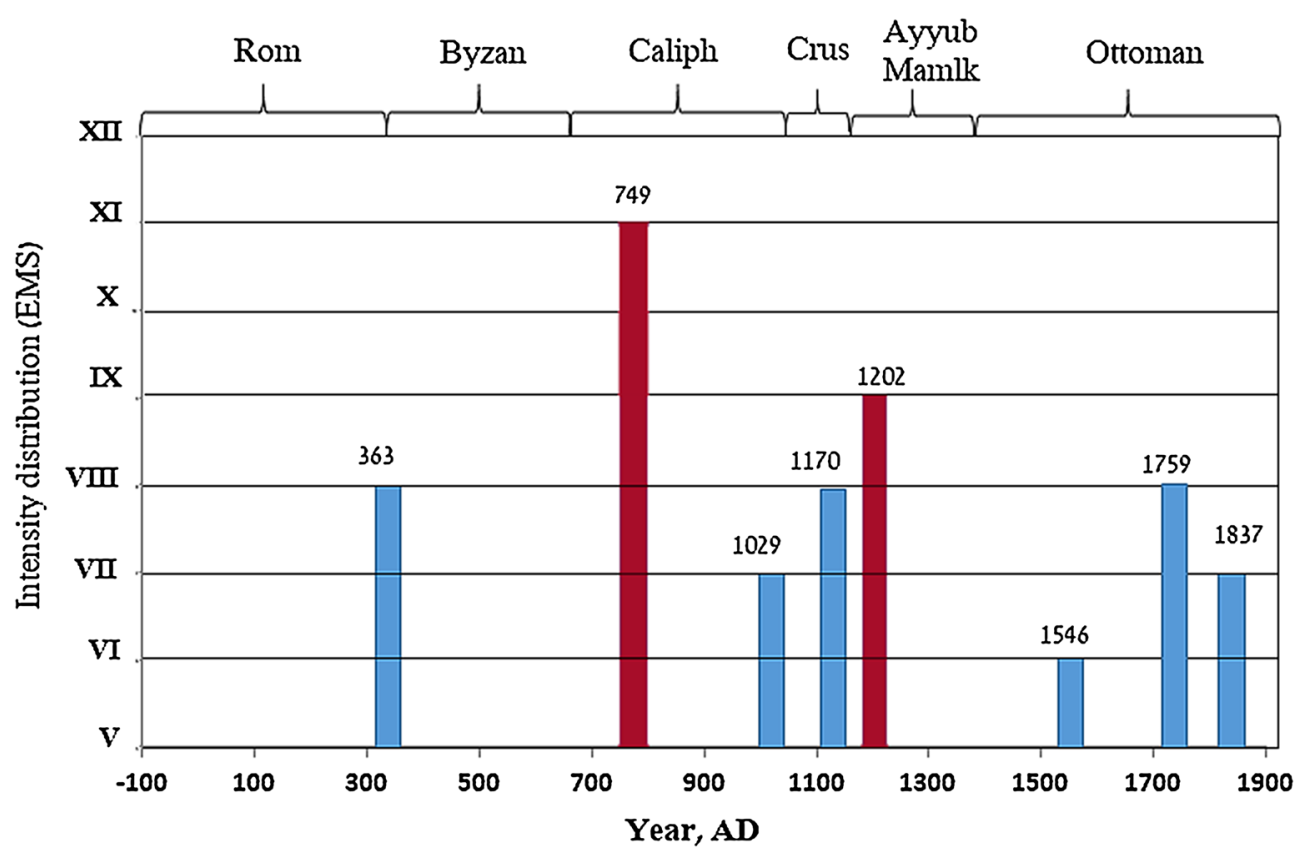

Fig. 8 Ancient earthquake chronology. Timeline of major earthquakes with potential to affect Qal'at al-Subayba, as a function of intensity values, according to the European macroseismic scale (VII, damaging; VIII, heavily damaging; IX, destructive; X, very destructive; XI, devastating). The values are based on Sbeinati et al. [24]). The earthquakes that hit the fortress are highlighted

Vadum Jacob (Ateret), studied by Ellenblum and Marco [26-28].

The Massive masonry of the Northwestern Tower requires special attention. It appears to be the earliest section built and its destruction predated other constructions at the site. Based on the extent of damage and the scattering radius of the stones, the earthquake that hit must have been of exceptional magnitude and 'devastating' intensity [29, 30]. Of the earthquakes described by Sbeinati et al. [24], the only earthquake of such scale is the A.D 749 quake, with an estimated intensity of XI on the European macroseismic scale. If this is the earthquake that struck the Massive masonry, then the fortress chronology is pushed back to, at least, 500 years. Previous publications have associated the Massive masonry to the Mamluks [3, 6]. This association was made based on a Mamluk inscription found at nearby wreckage [6] that could well be associated with the northern tower, which is known to be Mamluk. In addition, no other examples for such masonry in Mamluk construction have been documented for the entire region. Hence, this association of the massive masonry to the Mamluks seems to lack supporting evidence.

\section{The ancient origin of the fortress}

Massive stone masonry is a very complex and expensive. It requires sophisticated architectural knowledge, highly skilled stone dressers, professional masons, special instruments and a large workforce to move and maneuver the stones [22]. Although this masonry was never common, there are fine examples of it in antiquity [31]. Locally, however, with the exception of Jerusalem, this type of masonry is found only at Qal'at al-Subayba. In ancient time, massive masonry relied heavily upon slave labor. It was abandoned in the early medieval period and replaced by more efficient and less laborious methods. The Mamluks were highly skilled masons [32]. Nevertheless, they did not have the knowledge or the means to utilize this technology. If they did have such skill, as suggested by Hartal [6], there should be examples of massive masonry at other Mamluk sites [15].

The Massive masonry at Qal'at al-Subayba resembles Hellenistic fortifications rather than Herodian or Roman [33]. Greco-Hellenistic masonry, characterized by trapezoid ashlars, can be seen in Hellenistic fortifications in Asia Minor [34]. The large slits for arrow ballistas (polivolos katapeltes) in the secret passage (Fig. 3f) are also found in other Hellenistic fortresses. Edward Robinson (1856), the 19th century explorer, recognized these characteristics and suggested that Qal'at al-Subayba was established in ancient times, either by the Phoenicians or the Greeks [2].

One can argue that if Qal'at al-Subayba is, indeed, of ancient origin, then it would have been mentioned in 
historical records such as Maccabean and Josephus Flavius chronologies. While this assertion is reasonable, many of the sites mentioned in these records have not been positively identified. For some, the same geographic description is given for different names. Yet, for others, the same name is associated with different geographic descriptions [35]. Gamla, for example, is described in Flavius's The Jewish War IV as an isolated, naturally protected settlement situated upon a rough ridge between two deep valleys, and located at the lower Gaulanitis [36]. However, according to Flavius's Antiquities of the Jews 13 [37] and The Jewish War I, Gamla (Gamala) is a strong fortress on the northern Gaulanitis near a deep valley called Antiochus Trench ('Avтı́xou $\phi \alpha ́ \rho \alpha \gamma \gamma \alpha$ ). This fortress was taken by Alexander Janneus during his expedition to the north. Polybius, in The Histories, Book 16, recounts Zeno's telling of the battle of Panium. According to Zeno, Antiochus III (the Great) was positioned at the top of Mount Panium on the eve of the battle and his great victory over the Polemic Army [38].

It is possible to identify Mount Panium with the site of Qal'at al-Subayba. The fortress is situated on a narrow ridge with a protrusion resembling a camel hump, and the Antiochus Trench can be identified with the gorge of Wadi Sa'ar. It might be, therefore, that the fortress taken by Alexander Janneus and recorded as Gamla in Flavius's Antiquities of the Jews 13 and in The Jewish War I is actually the earliest record of Qal'at al-Subayba. If this is the case, the fortress might have been founded by Antiochus the Great himself. This hypothesis is highly hypothetical and must be supported by further excavation. The hypothesis would explain, however, the singular regional use of the highly complex, expensive, and laborious Massive masonry at Qal'at al-Subayba.

\section{Conclusion}

The characterization of the earthquake footprints on the different masonry styles at Qal'at al-Subayba indicates that the fortress was hit by two different earthquakes rather than one. These earthquakes were identified as the one of A.D 749 and the one of A.D 1202. Based on these findings, the fortress chronology can be divided into three different periods. Early (prior to the first earthquake), central (between the first and second earthquakes), and late (after the the second earthquake). The Massive masonry represents the early period, the Crusader masonry represents the central, and the Ayyubic and Mamluk masonries represent the late. This study provides firm evidence negating Ellenblum's Ayyubic Theory. The observation that large portions of the fortress were of Crusader masonry supports Deschamps' association of the fortress to the Franks [5]. However, the study also provides clear evidence for its ancient origin. Charles W. Wilson, in his A.D 1881 publication, Picturesque Palestine, describes the fortress as 'one of the strongest fortresses in the East, exhibiting the masonry work of every period from early Phoenician to Crusaders' [4]. This description accurately encompasses the fortress history.

The question of 'who built Qal'at al-Subayba' remains to be resoved. The Massive masonry carries typical Hellenistic characteristics. Therefore, it is suggested that it was founded by the Greco-Syrians. This hypothesis must be further investigated and additional archaeological research is imperative.

Authors' contributions

The author read and approved the final manuscript

\section{Acknowledgements}

I would like to thank Dr. Yinon Shavtiel, Dr. Ronnie Kamai and Giora Solar for fruitful discussion.

\section{Competing interests}

The author has no competing interests.

Availability of data and materials

The relevant data are presented within the main paper.

Consent for publication

Not applicable.

Ethics approval and consent to participate

Not applicable.

Funding

This work was not supported or funded by any means.

\section{Publisher's Note}

Springer Nature remains neutral with regard to jurisdictional claims in published maps and institutional affiliations.

Received: 4 July 2018 Accepted: 17 October 2018

Published online: 29 October 2018

References

1. Skolnik F, Berenbaum M, editors. Encyclopaedia Judaica. 2nd ed. Thomson Gale: Detroit; 2007

2. Robinson E. Later biblical researches in Palestine, and in the adjacent regions. A journal of travels in the year 1852. Drawn up from the original diaries, with historical illustrations, with new maps and plans. Boston: Crocker \& Brewster; 1856

3. Ellenblum R. Who Built Qal'at al-Subayba? Dumbart Oaks Pap. 1989:43:103-12

4. Wilson C. Picturesque Palestine. London: G. Virtue; 1880.

5. Deschamps P. Les Châteaux des Croisés en Terre Sainte. Volume II, La défense du royaume de Jérusalem tle. 1939.

6. Hartal M. The Al-Subayba (Nimrod) Fortress. IAA Report, No 11. Israel; 2001. p. 3-73.

7. Sharon M. Corpus inscriptionum Arabicarum Palaestinae (CIAP), vol. 2 Leiden: B-C. Brill Academic Publishers; 1999.

8. Wilson CW. Caesarea Philippi and the highlands of Galilee. Pict Palest Sinai, Egypt. D. Appelton \& Co; 1881. p. 336-58.

9. Hinzen K, Schwellenbach I, Schweppe G, Marco S. Quantifying earthquake effects on ancient Arches, example: the Kalat Nimrod Fortress, Dead Sea Fault Zone. Seismol Res Lett. 2016;87:751-64. 
10. Mare WH. The archaeology of the Jerusalem area. Grand Rapids: Baker Book House; 1987.

11. Nicolle D. Crusader Castles in the Holy Land 1097-1192. Oxford: Osprey Publishing; 2004.

12. Boas AJ. Crusader archaeology: the material culture of the Latin East. London: Routledge; 1999.

13. Gaetani A, Lourenco PB, Marcari G. Design and analysis of cross vaults along history. Artic Int J Archit Herit. 2016;10:841-56.

14. Amitai R. Ayyūbid Inscriptions at al-Subayba (Qal'at Nimrūd). Dumbart Oaks Pap. 1989;43:113-9.

15. Raphael K. Muslim fortresses in the Levant: between crusaders and Mongols. London: Routledge; 2010

16. Wilson JF. Caesarea Philippi: Banias, the lost city of Pan. New York: Tauris \& Co; 2004.

17. Lourenço P. Structural behavior of civil engineering structures: highlight in historical and masonry structures [Internet]. 2006. http://repositori um.sdum.uminho.pt/handle/1822/6436. Accessed 9 Aug 2017.

18. Zaineh HE, Yamanaka H, Dhakal YP, Dakkak R, Daoud M. Strong ground motion simulation during the November 1759 earthquake along Serghaya fault in the metropolitan of Damascus, Syria. J Seismol. 2013;17:1295-319.

19. Jäger W, Bakeer T. The effect of earthquake characteristics on the collapse of historical masonry buildings: case study of the mosque of Takiyya alSulaymaniyya. WIT Trans Built Environ. 2009;109:385-94.

20. Azevedo J, Sincraian G, Lemos JV. Seismic behavior of blocky masonry structures. Earthq Spectra. 2000;16:337-65.

21. Wilson JF. Caesarea Philippi: Banias, the lost city of Pan. New York: Tauris \& Co; 2004. p. 156-9.

22. Wright $\mathrm{GRH}$. Ancient building technology, vol. 3. Leiden, Boston: Brill Construction; 2009.

23. Ben-Menahem A. Earthquake catalogue for the Middle East (92 B.C.-1980 A.D.). Boll. di Geofis. Teor. ed Appl. 1979. p. 245-310.

24. Sbeinati, Darawcheh $R$, Mouty $M$. The historical earthquakes of Syria: an analysis of large and moderate earthquakes from 1365 B.C. to 1900 A.D. Ann Geophys. 2005;48:347-435.
25. Gibb HAR. The Damascus Chronicle of the Crusades: extracted and translated from the Chronicle of Ibn Al-Qalanisi. London: Luzac \& Co; 1932.

26. Khamisy R. Archaeological remains of the 1202 earthquake in the Frankish village of Tarphile/Khirbat al-Manhata'. Levant. 2017;49:333-41.

27. Ellenblum R, Marco S, Agnon A, Rockwell T, Boas A. Crusader castle torn apart by earthquake at dawn, 20 May 1202. Geology. 1998;26:303-6.

28. Zohar M, Salamon A, Rubin R. Earthquake damage history in Israel and its close surrounding - evaluation of spatial and temporal patterns. Tectonophysics. 2017;696-697:1-13.

29. Ambraseys NN. The seismic activity in Syria and Palestine during the middle of the 8th century; an amalgamation of historical earthquakes. J Seismol. 2005;9:115-25.

30. Marco S, Hartal M, Hazan N, Lev L, Stein M. Archaeology, history, and geology of the A.D. 749 earthquake, Dead Sea transform. Geology. 2003;31:665-8.

31. Wright $\mathrm{GRH}$. Ancient building technology/1, Historical background. Leiden: Brill; 2000

32. Hamdouni Alami M. Art and architecture in the Islamic tradition : aesthetics, politics and desire in early Islam. London: I.B. Tauris; 2011.

33. Müth S, Schneider PI, Peter I, Schnelle M, De Staebler PD. Ancient fortifications : a compendium of theory and practice. Philadelphia: Oxbow Books; 2016.

34. McNicoll A, Milner NP. Hellenistic fortifications from the Aegean to the Euphrates. In: Milner N., editor. Oxford: Clarendon Press; 1997.

35. Hartal M. History from Land of Ituraen [Internet]. Katsrin: ha-Makhon le-heker ha-Golan ; ha-Muze' on le-'atiḳot ha-Golan; 2005. https:// www.academia.edu/4819889/Hartal_-History_from_Land_of_Ituraen. Accessed 13 Jul 2016.

36. Josephus F. The Jewish war. Baltimore Md.: Penguin Books; 1960.

37. Josephus F. Antiquities of the Jews. Dinslaken: Anboco; 2016.

38. Paton W. Polybius, the histories, Volume V: Books 16-27| Loeb Classical Library. Cambridge: Harvard University Press; 2012.

\section{Submit your manuscript to a SpringerOpen ${ }^{\circ}$ journal and benefit from:}

- Convenient online submission

- Rigorous peer review

- Open access: articles freely available online

- High visibility within the field

- Retaining the copyright to your article

Submit your next manuscript at springeropen.com 